\title{
НЕЙРОТРОПНЫЕ СВОЙСТВА КАРКАСНЫХ СОЕДИНЕНИЙ
}

\section{Ю.Н. Климочкин}

Кафедра органической химии, Самарский государственный технический университет, 443100, Россия, г. Самара, Молодогвардейская, 244.

DOI: 10.19163/MedChemRussia2021-2021-15

E-mail: klimochkin.yn@samgtu.ru

Функциональные производные адамантана и родственных каркасных структур широко используются в терапии нарушений центральной нервной системы. Многие молекулы каркасного строения находятся на различных стадиях доклинических и клинических испытаний.

В докладе рассматриваются некоторые исторические аспекты медицинской химии производных адамантана, синтетические подходы к используемым в терапевтической практике лекарствам адамантаного ряда, аспекты синтеза оригинальных молекул каркасного строения с установленным нейротропным действием. Приводятся данные по синтезу конформационно ограниченных аналогов ГАМК каркасной структуры, в том числе нерацемических, а также некоторые предварительные результаты изучения их нейротропного действия. 